\title{
Calcium soap from palm fatty acid distillate for ruminant feed: $\mathrm{Ca}(\mathrm{OH})_{2}$ as calcium source
}

\author{
Lienda A. Handojo*, Antonius Indarto, Dian Shofinita, Anggina Meitha, Rakhmawati \\ Nabila, Harry Triharyogi, Maulana G.A. Hakim, and Muhammad R. Saadi \\ Department of Chemical Engineering, Faculty of Industrial Technology, Institut Teknologi Bandung, \\ 40132 Bandung, Indonesia
}

\begin{abstract}
PFAD can be utilized as raw material for producing calcium soap, a kind of ruminant feed supplement. It gives benefits to the ruminants' health and increases the quantity and quality of cattle's milk. This research evaluated the effect of stoichiometric mole ratio of $\mathrm{Ca}(\mathrm{OH})_{2}$ to PFAD and water temperature on calcium soap production using PFAD and calcium hydroxide as raw materials by applying modified fusion method. The result showed that the acid value of products decreased as the mole ratio of $\mathrm{Ca}(\mathrm{OH})_{2}$ to $\mathrm{PFAD}$ increased and the low water temperature lowered the acid value of products. The highest fatty acid conversion $(98 \%)$ was achieved at the stoichiometric mole ratio of 3 . However, the use of such high mole ratio is not preferable because the product will have excessive calcium, which may disturb the absorption of other minerals in ruminant's digestion. Thus, further research related to operating condition and the use of other calcium sources in the calcium soap production is still required.
\end{abstract}

\section{Introduction}

Indonesia is the largest world palm oil producer, with 32.5 million tonnes of palm oil annual production (Indonesian Palm Oil Producers Association, 2016). This is equal to approximately $54 \%$ of world's total palm oil production (USDA, 2016). Refining process of crude palm oil produces palm fatty acid distillate (PFAD), a by-product which contains free fatty acid. Countries such as USA and UK used PFAD as animal feed, laundry soap, and raw materials for oleochemistry and biofuel industries [1]. Utilization of PFAD in Indonesia is not optimum and it is predominantly exported without further processing.

PFAD can be utilized as raw material of animal feed supplement after reacted with calcium in the form of protected fat [2]. It functions as an energy source for cattle and has positive effects on milk productions [3-5] as well as the fertility of cattle [5, 6]. Giving calcium soap $0.45 \mathrm{~kg} /$ day to the cows can increase milk production by $3-8 \%$ [4]. Fatty acids need to be converted into soap before being consumed, as the direct consumption of fatty acids by cattle can disrupt the activity of digestive bacteria in cattle rumen [2].

\footnotetext{
*Corresponding author: lienda@.che.itb.ac.id
} 
Based on above information, this study was conducted to evaluate the production of calcium soap from PFAD. Modified fusion reaction allows fatty acid to react with calcium source in the form of its oxide and hydroxide [7]. This research evaluated the effect of calcium source of $\mathrm{Ca}(\mathrm{OH})_{2}$ and the operating conditions of saponification reaction on the acid value of resulting product. Acid value was used as the basis of reaction evaluation as it indicates the amount of fatty acid converted into product.

\section{Working procedures}

\subsection{Materials}

The main materials used in this research were technical grade $\mathrm{Ca}(\mathrm{OH})_{2}$ as the source of calcium and PFAD from PT Tunas Baru Lampung Tbk. as the source of fatty acid.

\subsection{Methodology}

In general, research conducted by reacting PFAD with $\mathrm{Ca}(\mathrm{OH})_{2}$ using modified fusion method $[8,9] . \mathrm{Ca}(\mathrm{OH})_{2}$ was added to 50 grams of molten PFAD and stirred until homogeneous. Then followed by the addition of $10 \mathrm{~g}$ of water, or equivalent to $20 \%$ of the mass of PFAD.

Stoichiometric mole ratio of $\mathrm{Ca}(\mathrm{OH})_{2}$ to $\mathrm{PFAD}$ were varied from 1 to 3 , while water temperature was between 60 and $80^{\circ} \mathrm{C}$. The products were evaluated through the acid value measured using ISO 660: 1990, and moisture content of the product based on ASTM D3173. Reaction conversion was estimated by calculating the amount of free fatty acid as palmitic acid of PFAD that was consumed at the saponification reaction, or simply by calculating the percentage difference of the acid value of the product and PFAD.

\section{Analysis}

\subsection{The effect of the variation of stoichiometric mole ratio and water temperature on the acid value of product}

The acid value is one of the parameters for determining the extent of the saponification reaction and representing the percentage of conversion reaction. The smaller the acid value of calcium soap products, means higher fatty acids have been converted to soap. Results of the study showed that PFAD used in this experiment had an average acid value of 180-205 $\mathrm{mg} \mathrm{KOH} / \mathrm{g}$ sample [10]. Figure 1 shows the effect of stoichiometric reactant mole ratio and water temperature to acid value. 


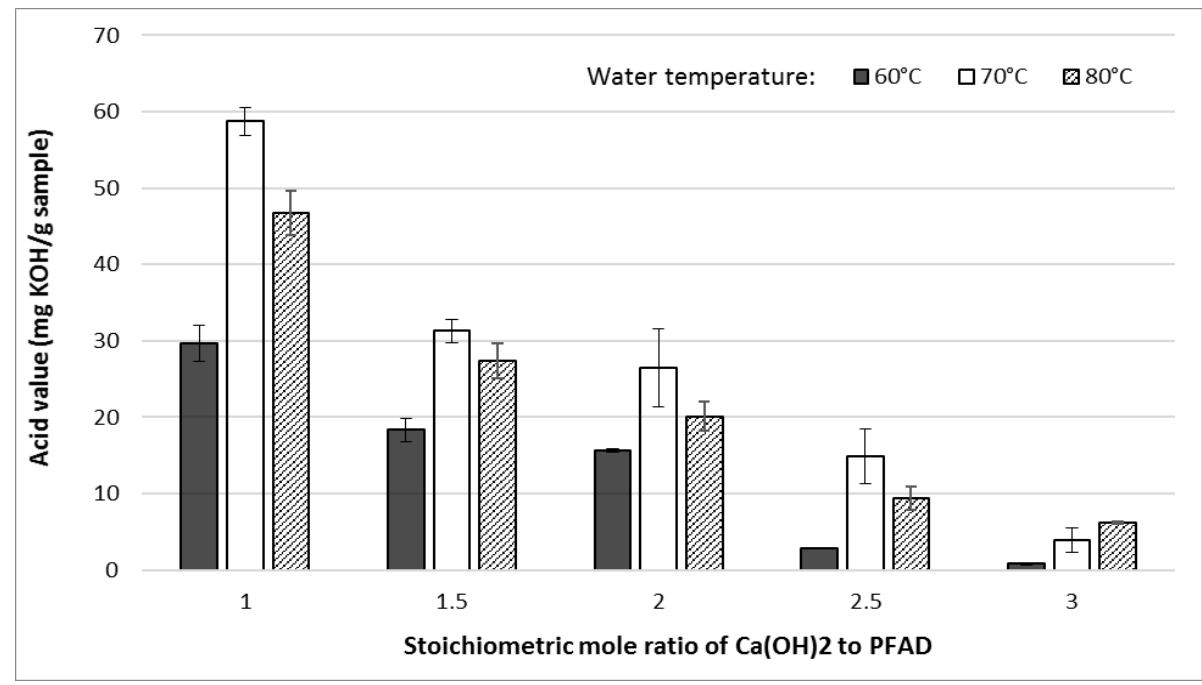

Fig. 1. Acid value of the calcium soap in variations of reactant mole ratio and water temperature.

In the mole $\mathrm{Ca}(\mathrm{OH})_{2}$ to $\mathrm{PFAD}$ ratio of 1.5 with water temperature of $60^{\circ} \mathrm{C}$, the acid value of the soap was high $(29.6 \mathrm{mg} \mathrm{KOH} / \mathrm{g}$ sample), which means only about $84 \%$ fatty acid in PFAD was converted into calcium soap. The highest conversion occurred at the highest mole ratio of calcium to PFAD. With a mole ratio of 3 , the conversion of fatty acids reached an average of $98 \%$. These showed a consistence with the equilibrium reaction theory that the equilibrium shifts to the right as the reactant concentration increases.

However, feeding the excessive calcium content can inhibit the absorption of other minerals such as zinc and phosphorus in cattle digestion [11]. One of the factors affecting phosphorus absorption efficiency is the ratio of calcium to phosphorus. Based on the study, the recommended supplemental calcium for cattle is not more than $50.7 \mathrm{~g} /$ day [12]. With an optimum calcium-to-phosphorus ratio of 1.75 , feeding excessive calcium without offsetting the addition of phosphorus can inhibit the phosphorus uptake [13]. Calcium soap with mole ratio of 1 and 1.5 that would meet the recommended amount of calcium consumption for cattle [4].

Water temperatures did not show a regular trend to the acid values of product. The lowest acid value was obtained at $60^{\circ} \mathrm{C}$, then followed by $80^{\circ} \mathrm{C}$ and $70^{\circ} \mathrm{C}$ respectively. This means that the highest conversion occurred at a lower temperature. This was related to the saponification reaction which is an exothermic reaction. Lower water temperatures will lead the reaction going towards the product, resulting a higher conversion of reaction.

\subsection{The effect of the variation of stoichiometric mole ratio and water temperature on the moisture content of product}

The added water and resulted water from the saponification reaction affected the moisture of the product. High water content will cause the soap textured wet and soft, while the small moisture content made the soap textured dry, hard, and be easily grinded into powder. The profile of moisture content of the calcium soap product is shown in Figure 2. 


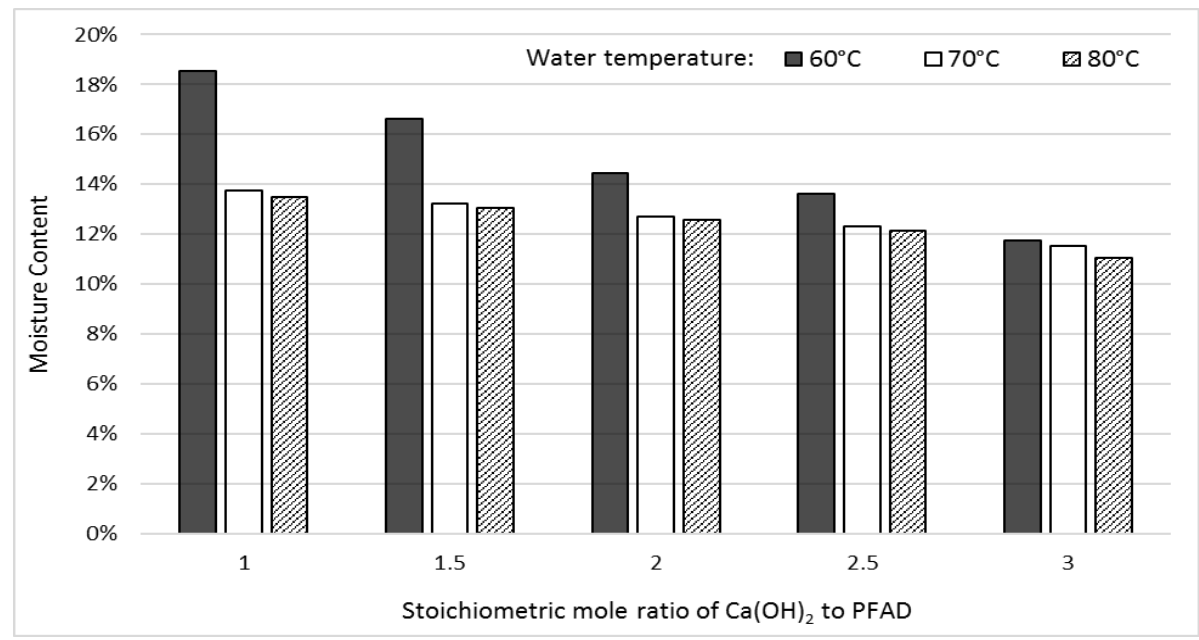

Fig. 2. Moisture content of the calcium soap in variations of reactant mole ratio and water temperature.

Based on Figure 2, the more amount of added calcium, the lower the moisture content of the soap. It was related to the saponification reaction that is exothermic. Larger amount of calcium would convert more fatty acids and produced more heat, which in turn gave rise to the temperature of the system. As a result, the water in the system evaporated with a larger amount along with the rise in temperature. Based on Figure 3, it can be seen that high peak temperature causes the lower moisture content.

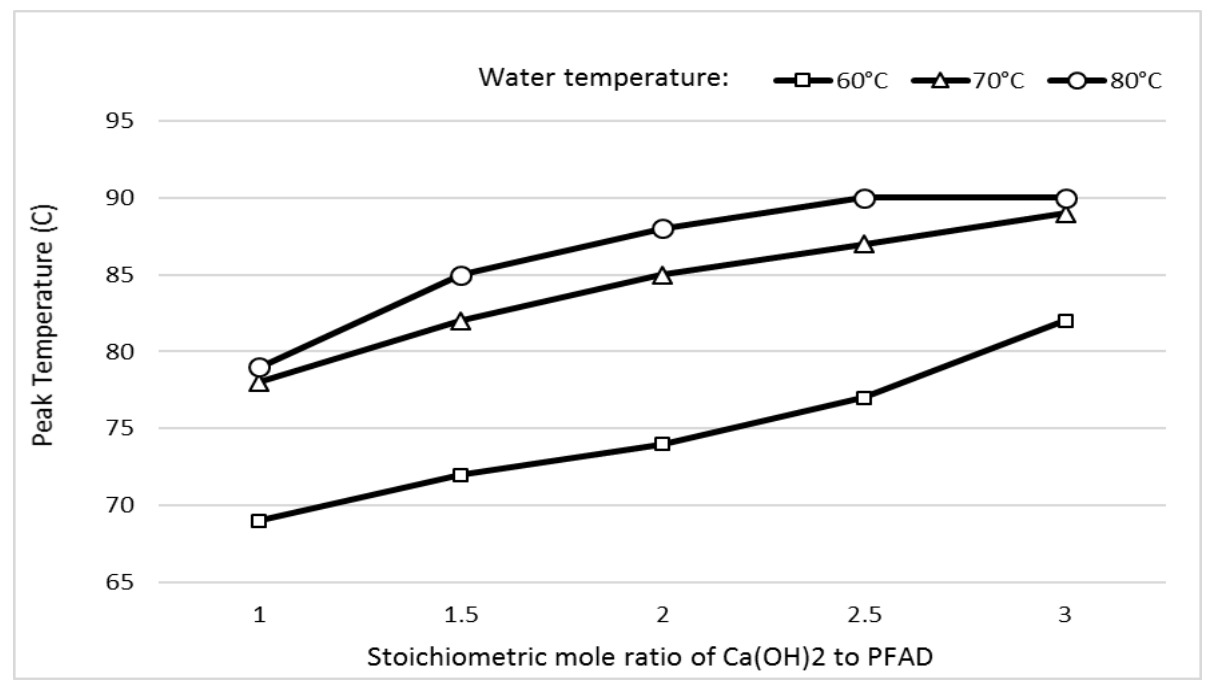

Fig. 3. Peak temperature in variations of reactant mole ratio and water temperature.

In variation in water temperature, the higher water temperature would produce soap with lower moisture content. This relates to the amount of heat available to evaporate water. Higher water temperatures provided more heat, characterized by the peak temperature values. As a result, water evaporated in a larger amount along with the presence of more heat.

The moisture content of calcium soap was still higher than commercial calcium soap which is in the range of $3-5 \%$ because of the absence of drying process. This indicated that 
the mole ratio of $\mathrm{Ca}(\mathrm{OH})_{2}$ and water temperature could not produce soaps with moisture content close to the commercial product. Another study showed that when the mole ratio of calcium to PFAD was 1 , soap with $\mathrm{CaO}$ as the calcium source has an average moisture content of $8.7 \%$, relatively lower than the soap using $\mathrm{Ca}(\mathrm{OH})_{2}$ that was $18.5 \%$ [10]. The use of calcium oxide allowed water to react with $\mathrm{CaO}$ forming $\mathrm{Ca}(\mathrm{OH})_{2}$, which then react with the fatty acids. So, when water is used in the same amount, the fatty acid reaction with calcium oxide will produce water in the final product less than using calcium hydroxide.

\section{Conclusion}

This experiment evaluated the process of producing calcium soap from PFAD using $\mathrm{Ca}(\mathrm{OH})_{2}$ as calcium source. The reactants mole ratio and water temperature could influence the characters of calcium soap, noticed from the value of acid number and moisture content. The increasing amount of calcium lowered the acid value, indicating the high conversion of the saponification reaction. In this experiment, the highest fatty acid conversion was obtained at the stoichiometric mole ratio of $\mathrm{Ca}(\mathrm{OH})_{2}$ to PFAD mole of 3, with an average conversion value of $98 \%$. The stoichiometric mole ratio of 1 and 1.5 meets the recommended supplemental calcium. The characteristic analyzed, physical appearance, and the texture of all experimental products showed a low similarity to the commercial soap. Therefore, further research is necessary to be conducted especially regarding the effect of other sources of calcium on the character of soap.

\section{Acknowledgements}

The authors would like to extend their sincere gratitude to BPDPKS Indonesia 2016 for supporting and enable the authors to conduct this research and PT Tunas Baru Lampung Tbk for providing PFAD for this research.

\section{References}

1. A.G.M. Top, Lipid Tech. J. 22, 13 (2010)

2. J. Waters, Fat supplements for dairy cows (2010)

3. E. Block, W. Chalupa, E. Evans, T. Jenkins, P. Moate, D. Palmquist, C. Sniffen, Calcium salts are highly digestible (2005)

4. Volac International Ltd. Megalac product sheets (2016)

5. E. Wina, Susana IWR, WARTAZOA 23, 176 (2013).

6. U. Moallem, M. Katz, H. Lehrer, L. Livshitz, S. Yakoby, J. Dairy Sci. 90, 1243 (2007)

7. R. H. Rogers, W.R. Blew, US Patent 2890232 (1984)

8. H.L. Blachford, US Patent 4316852 (1982)

9. W. McAskie, US Patent 4826694 (1989)

10. L. Handojo, A. Indarto, D. Shofinita, A. Meitha, R. Nabila, H. Triharyogi, Medwell J. (to be published)

11. D.L. Palmquist, T.C. Jenkins, J. Dairy Sci. 67, 978 (1984)

12. NRC, Nutrient requirements of dairy cattle (2001)

13. A.C. Field, J. Kamphues, and J.A. Woolliams, J. Agr. Sci. 101, 237 (1983) 